\title{
Preliminary results of new elastic mini-nail in the distal radius fractures. First 83 cases of the nail-o-flex nail
}

Persoons $\mathrm{D}^{1}$

${ }^{1} \mathrm{CH}$ Saverne, Bas-Rhin, France

Corresponding Author: Dominique Persoons, Ph D

Address: CH Saverne, Bas-Rhin, France; E-mail: persoons@email.fr

Received date: 23 August 2019; Accepted date: 04 September 2019; Published date: 10 September 2019

Citation: Persoons D. Preliminary results of new elastic mini-nail in the distal radius fractures. First 83 cases of the nail-o-flex nail. Asp Biomed Clin Case Rep. 2019 Sept 10;2(2):34-43.

Copyright (C) 2019 Persoons D. This is an open-access article distributed under the Creative Commons Attribution License, which permits unrestricted use, distribution, and reproduction in any medium, provided the original work is properly cited.

\begin{abstract}
The distal radius fracture is a common injury in old persons. His treatment remains a critical challenge because of number of cases, the final cost of the procedure, the level of X-rays irradiation and a demanding technic of fixation in osteoporotic bone. The entire closed procedure requires a strict percutaneous nailing. This offers advantages in terms of post-operative pain, per-operative irradiation and cost. The main problem was so far the ability to insure a stable reduction in time. This point is discussed with the introduction of the "Nail-oflex ${ }^{\circledR}$ " nail. A continuous series of 83 patients is introduced.
\end{abstract}

\section{Keywords}

Radius Fracture; Distal Radius Fracture; Non-Invasive Surgery; Nail; Nail-o-Flex

\section{Introduction}

The fracture of the distal radius is very common [1] and even the third most frequent among seniors (15\% of the fractures amongst the elderly). It is estimated that 150,000 people sustain a distal radius fracture every year in France [2]. The simplicity, the efficiency and the low cost of the surgical procedure are decisive factors in terms of public health. Therefore, their mechanism should better be fully understood [3-5]. The challenge in the Colle's fractures is to maintain an appropriate reduction when the spongious bone is collapsed. How to treat this bone void? The nailing seems to gain, year after year, an important place in the treatment of the distal radius collapse, probably for its particular ability to restore and maintain the radial length.

The radius is a long, relatively straight bone, and frequently subject to fractures because of its protective role in the event of a fall or accident. The long wires were first used during the First World War while the flexible pins were described as early as the 1950 s. Several types of flexible nails dedicated to distal fractures appeared in the early 2000s. Today, there are specifically designed wires for fractures of the radial diaphysis.

\section{Material}

\section{The compaction chamber:}

During a fall, the wrist undergoes a force of compression and flexion which causes a crush of the bony trabecular structure of the distal radius. The cortical break comes along with the flattening of the deep cancellous bone. The first principle of a closed nailing is to recognize the existence of a "compaction chamber", that is to say a void of bone. The aim is to reopen this chamber and keep its banks well apart to 
Citation: Persoons D. Preliminary results of new elastic mini-nail in the distal radius fractures. First 83 cases of the nail-o-flex nail. Asp Biomed Clin Case Rep. 2019 Sept 10;2(2):34-43.

\section{Original Article}

restore the length of the radius. The elasticity of the nail has to enable to maintain this opening. This principle was described by Desmanet in 1989 [6].

Some implants have even been specially designed to fill the void of the compaction chamber (Fig-1).

Those expandable devices have the disadvantage of being bulky and not providing any mechanical

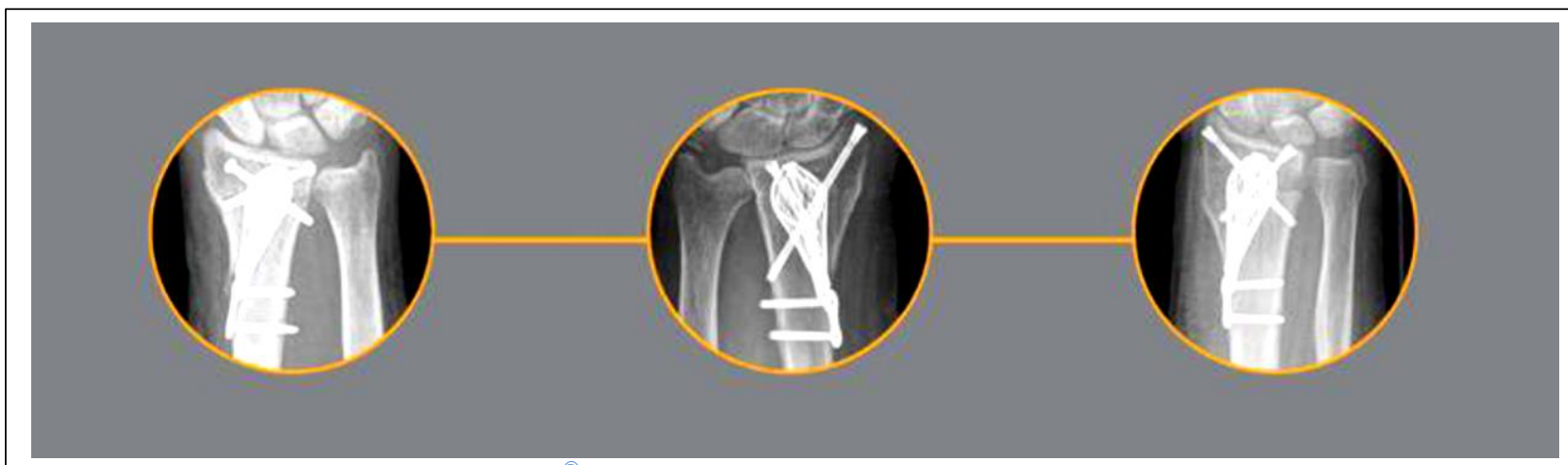

Fig-1: implant expansible Conventus DRS

stability. However, they widely open the fracture focus and they offer the advantage of showing the volume of bone loss at the distal metaphysis level.

\section{The reduction:}

The fracture of the distal radius is reduced by manual traction. It disimpacts the fracture site and reopens the metaphysis. The nail, as a central stake, maintains the reduction and the void thus created. The aim of a percutaneous nailing is to restore the radius length and to reduce the distal radio-ulnar joint. The principle is to keep the bone aligned by the help of a stable intramedullary distractor. A locking device of the distal extremity is absolutely necessary

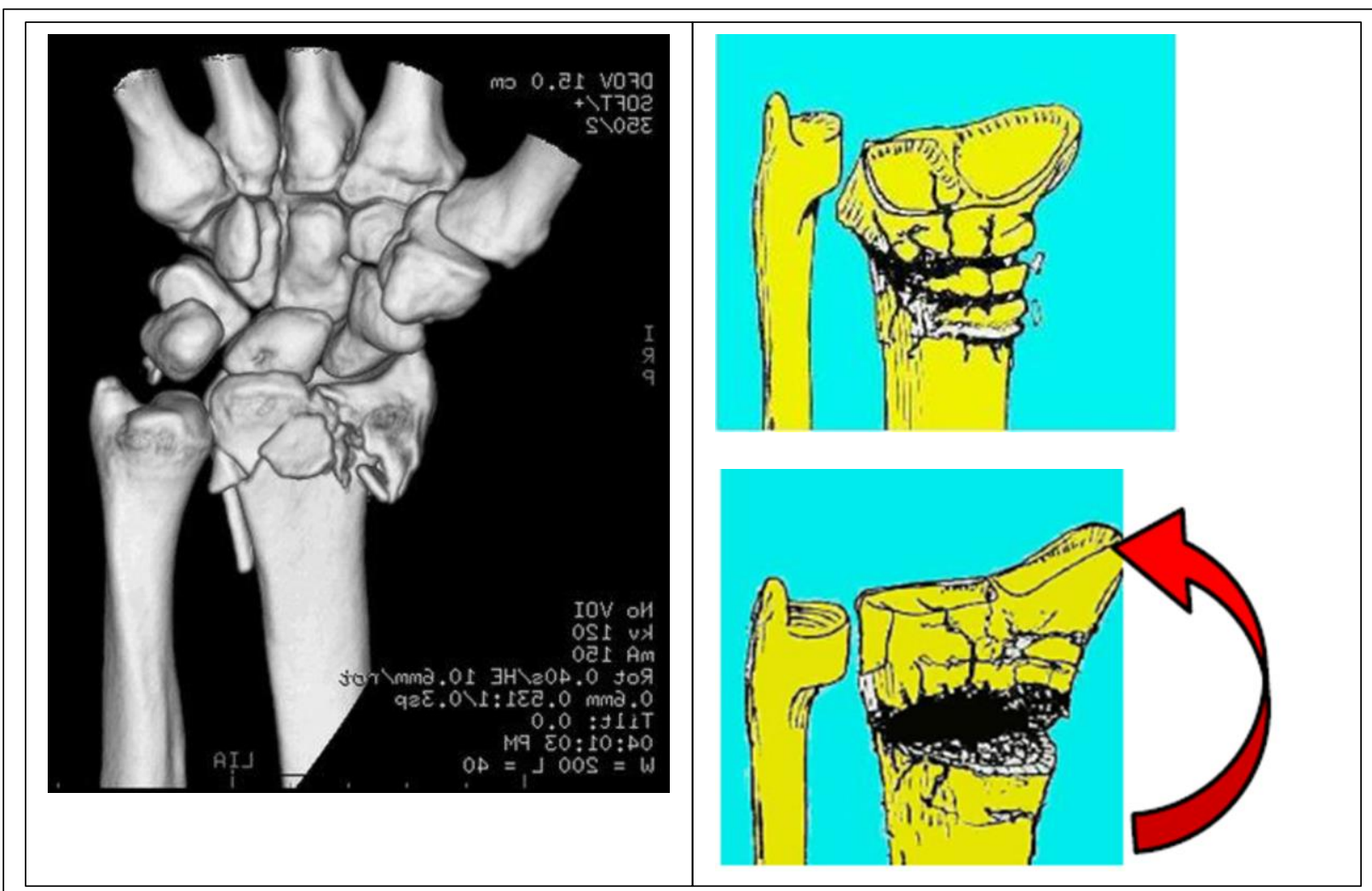

Fig-2:

fracture of the distal radius with the crushing of the metaphyseal bone. Reopening of the fracture site. The aim is to maintain it open. 
Citation: Persoons D. Preliminary results of new elastic mini-nail in the distal radius fractures. First 83 cases of the nail-o-flex nail. Asp Biomed Clin Case Rep. 2019 Sept 10;2(2):34-43.

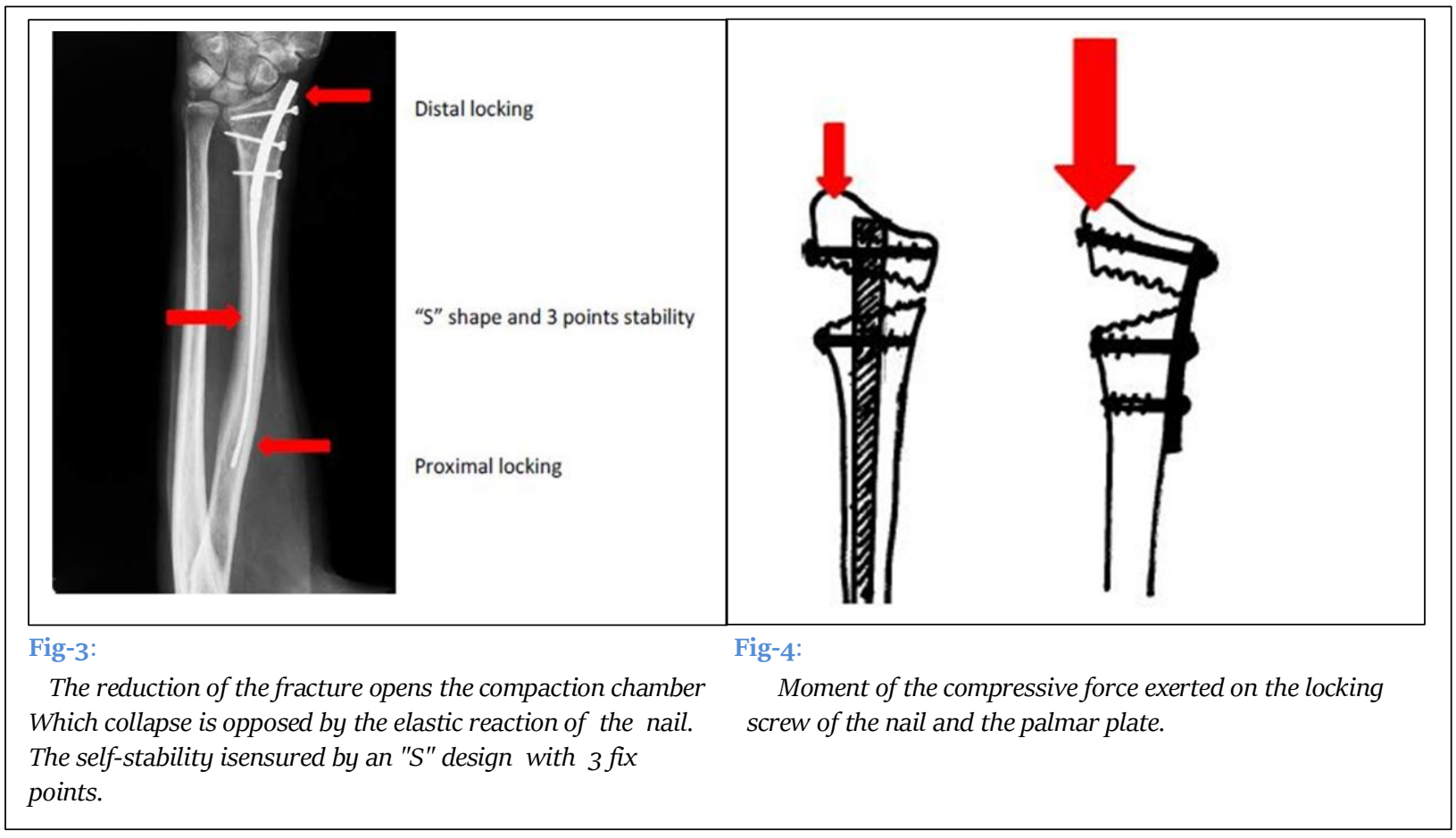

1)

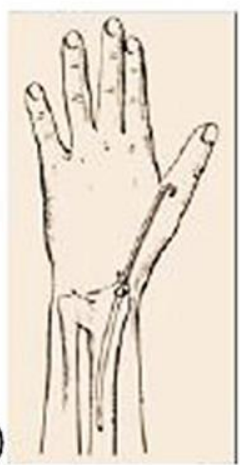

5)

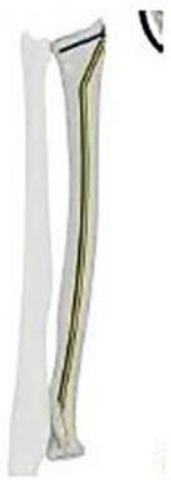

2)

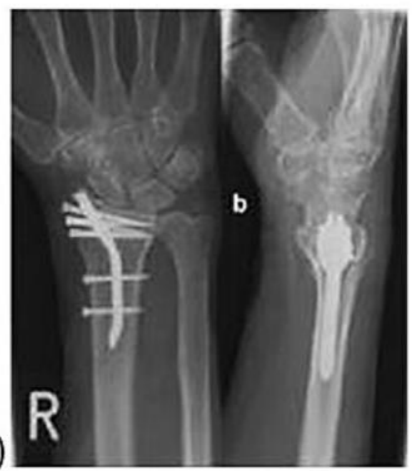

6)

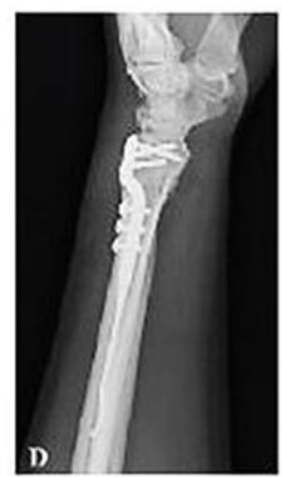

3)

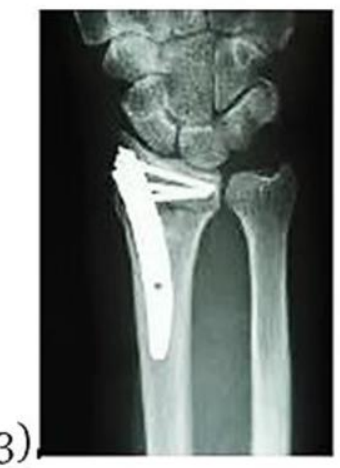

4),

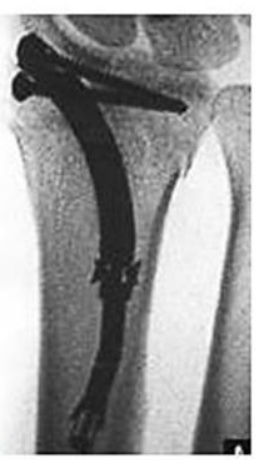

7)

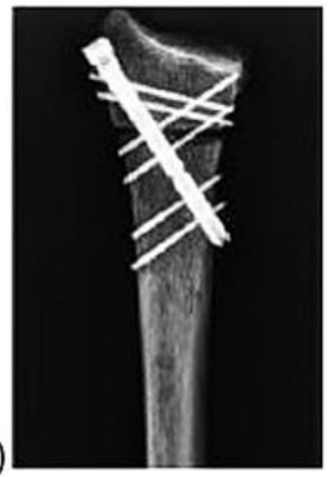

Fig-5:

Different nails for the distal radius fractures 1) Rusch nail (1955) 2) "targon“" ${ }^{\circledR}$ nail, 3) “micro-nail“" ${ }^{\circledR}$ 4) “Sonoma“ “ ${ }^{\circledR}$ nail 5) “Rin““ ${ }^{\circledR}$ nail 6) "DNP“( ${ }^{\circledR}$ dorsal nail-plate 7) Zimmer “X-Screw““ ${ }^{\circledR}$ locked screw. 


\section{Original Article}

in order to perform a stable alignment (static nailing). Dynamic nailing would result in a secondary collapse of the radius (Fig-2-4).

\section{Nailing history:}

The principle of nailing the long bones fractures was described by R. Danis of the University of Brussels (Belgium) in 1938 followed by G. Küntscher at the University of Kiel (Germany) in 1939 [7] . The later used his nails on the wounded of the Finnish front during the Second World War [8]. The transverse locking of the nail has been described by Modny and Bambara in 1953 [9]. This lock was improved by Kempf and Grosse [10] in 1978 to the point where it prevailed over the screw plate osteosynthesis which was very popular in the 1960-1980. This method has revolutionized the treatment of long bones fractures of the lower limbs. Since the year 2000, it has been applied to the upper limb by drawing smaller, miniaturized nails as it were. The goal was to go back to closed-focus osteosynthesis, as done for the lower limbs (Fig-5).

Most recent series seem to show the equivalence of radiological and functional results, between closed nailing and the anterior plates. Grad \& Milka say in 2014, into "Injury" Orthopedic Journal that: "The present study supports the view that intramedullary nail fixation and flat fixation for the treatment of displaced extra-articular distal radius fractures have equivalent radiographic and functional outcomes" [11].

Nail-o-flex ${ }^{\circledR}$ nail:

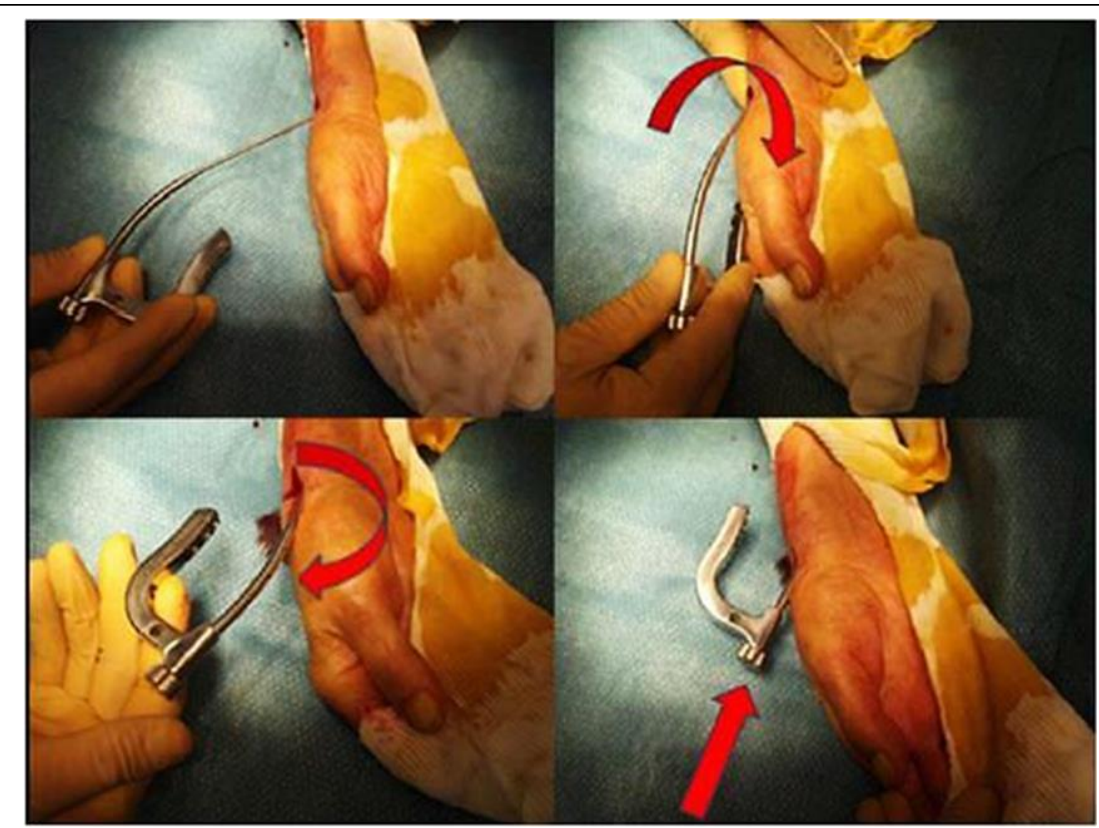

Fig-6:

Major point: the nail is introduced in reversed position. It is turned $180^{\circ}$ as long as pushed forwards. A "clic" is heart by the time the fracture is reduced.

The Nail-o-flex ${ }^{\circledR}$ nail was introduced in 2005. It is a specific nail for fractures of the distal radius. It comprises a distal portion which is perforated and a long, smooth proximal part that is thin and flexible to ensure elasticity. The "Nail-o-flex ${ }^{\circledR}$ " nail application technique is directly derived from the long bones nailing of the lower limb (Fig-6).

The radius fracture is reduced by manual traction. The nail is inserted at the level of the snuffbox, outside the tendinous areas. The entrance is perforated with a small square point. The nail has an "S" shape. It is inserted with curvature upside down to fit the metaphyseal angle, it is then turned over and entirely inserted. It is stopped by the aiming frame which stumbles on the radial styloid. Locking is performed as for the femur or tibia. The nail is freestanding thanks to its "S" design and its 3 points of support. It is also elastic since the $2 / 3$ of the nail are fine as a pin $(2 \mathrm{~mm})$ and automatically realigns the distal epiphysis and keeps the focus open. It must be locked at its distal part, with at least two epiphyseal screws (Fig7). 

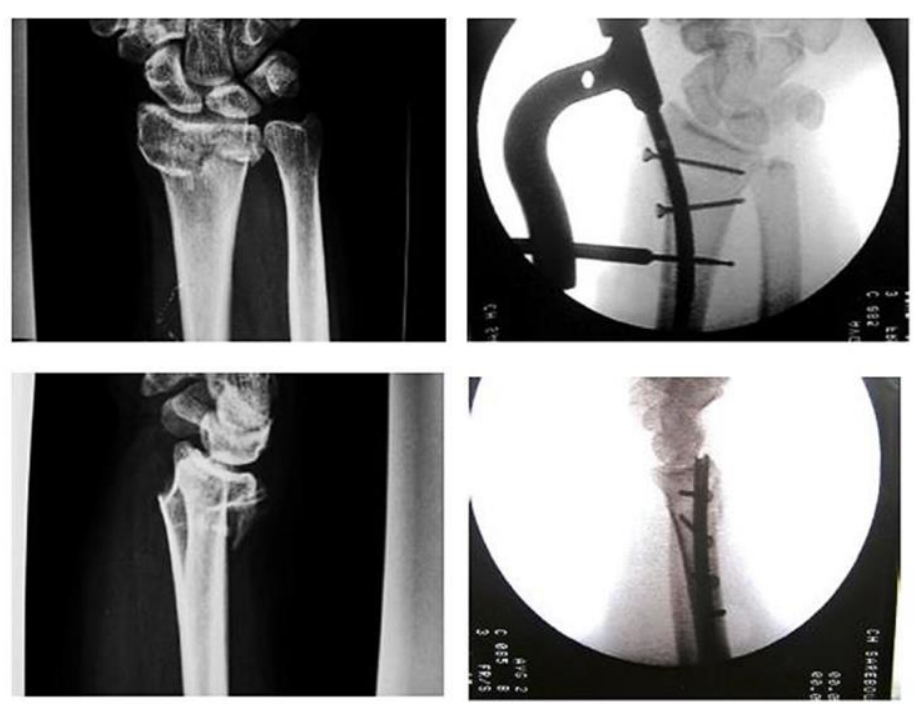

Fig-7:

Radiological aspects of the reduction and nailing of a distal radius fracture

\section{Method}

Between May 2008 and May 2015, the Nail-o-flex ${ }^{\circledR}$ nail was used to treat fractures of the lower end of the radius. All cases presenting an extraarticular fracture (Colles or Smith) and/or an intra-articular fractures (except marginal fracture and comminuted fractures with 4 fragments or more) have been treated. The preliminary series includes 83 cases.

Of these 83 cases, the female/male ratio was 7 to 1 . The average age was 63 years, ranging from 18 to 89 years. Average operating time was 45 minutes. The hospital stay was 2 days up to 2013, when all these fractures were then treated as outpatients. A Velcro splint has been routinely used for a period of 5 weeks. The clinical results were analyzed with the Constant score: 55 excellent, 20 satisfactory and 8 poor result. There was no redo for insufficient result. Fractures have been classified according to Laulan and Bismuth [11].

The purpose of this Clinical Series was to confirm that metaphyseal bone defect could be treated with an elastic nail according to the principle of Desmanet, without graft or surrogate, and that the distal epiphyseal lock was sufficient to keep the epiphyseal fragments in a good position during the entire consolidation period. In this series, we have shown that $75 / 83$ cases had retained a radio-ulnar index less than or equal to $\mathrm{o}$. This shows a good restoration of the length of the radius. These cases correspond to the 75 cases excellent and good cases of the preseries.

\section{Discussion}

The nailing of the fractures of the radius is an outsider because there is a kind of unanimity about the anterior screwed plate. One can criticize plates to be inserted openly opposite to the damaged area. This can be the source of additional pain. However mininails of the radius have been compromised by unreliability and limited indications. None of them had incorporated the need for an elastic recall force to oppose the natural compaction of the compaction chamber. This is the originality of the nail-o-flex ${ }^{\circledR}$ nail.

The nail-o-flex ${ }^{\circledR}$ nail is a "nail-pin" device that combines a distal stable locking according to Kempf and Grosse and a proximal elasticity according to Desmanet. As so, it can behave like an internal distractor. Improvements have been made on the quality of the locking screws and the accuracy of the viewfinder. Today this nail is a simple to use for any operator familiar with the femur or tibia nails.

\section{The compaction chamber:}

The first question in the distal radius fractures seems the loss of bone matter in the metaphyseal region due to the flattening of the spongy bone. The 


\section{Original Article}

clinical series has shown that the radius only recoils in $6 \%$ of cases $(78 / 83)$, whereas this complication was frequent with the Kapandji type entanglements. Efficiency seems to be due to the fact that the nail acts as a central guardian, without shear stress.

\section{The reduction must be stable:}

Secondarily, to maintain a quality epiphyseal, reduction is relevant. The use of palmar plates may seem paradoxical since the bone commination is mainly on the opposite side $[12,13]$. The operator does not have access to it. Even self-stable screws cannot replace a missing bone. Many authors question themselves about this method which is widely diffused [13-15]. The intramedullary percutaneous nail is mechanically more logical $[16,17]$. It is central, thus more neutral and simple to use. Lateral approach is direct and offers more security.

\section{Accurate reduction:}

To maintain a good orientation of the radial epiphysis: The functional result is good if the $15^{\circ}$ epiphyseal anteversion is restored. One tolerates a tilting of only a few degrees because it does not have any impact on the degree of flexion of the wrist. But a retroversion of the epiphysis was considered a poor result, even if the index radio-ulnar remained equal to zero. We found 7 poor cases, mainly at the beginning of the series. However, the absence of shortening of the radius made it possible to maintain normal pronosuppination. Patients therefore did not feel the need for a redo.

\section{Pain control:}

The painful assessment is favorable. It is recognized that closed osteosynthesis are less painful than open procedures as screwed plates [17]. This was notified by Kempf an Gross in the 1970, in lower limbs fractures.

\section{Aesthetics:}

The aesthetic aspect is interesting. The intervention is conducted by 3 or 4 holes of 2 or $3 \mathrm{~mm}$ (Fig-8). 
Citation: Persoons D. Preliminary results of new elastic mini-nail in the distal radius fractures. First 83 cases of the nail-o-flex nail. Asp Biomed Clin Case Rep. 2019 Sept 10;2(2):34-43.

\section{Original Article}

Results of the clinical series (2008-2017) (Table-1)

Table 1 : clinical series: A continuous series of 83 cases of distal radius fractures treated with percutaneous

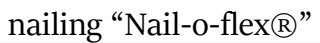

\begin{tabular}{|c|c|c|c|c|}
\hline S.No & Laulan \& Bismuth Class & DRU & Anteversion & Functional Result \\
\hline 1 & $\mathrm{M}_{4} \mathrm{E}_{3} \mathrm{C}_{1}$ & -1 & $\mathrm{O}$ & Excellent \\
\hline 2 & $\mathrm{M}_{4} \mathrm{E}_{3} \mathrm{Co}$ & -2 & -10 & Good \\
\hline 3 & $\mathrm{M}_{4} \mathrm{E}_{4} \mathrm{C}_{1}$ & $\mathrm{o}$ & -5 & Good \\
\hline 4 & $\mathrm{M}_{4} \mathrm{E} 2 \mathrm{Co}$ & $\mathrm{o}$ & 5 & Excellent \\
\hline 5 & $\mathrm{M}_{4} \mathrm{E}_{3} \mathrm{C}_{1}$ & $\mathrm{o}$ & 5 & Excellent \\
\hline 6 & $\mathrm{M}_{4} \mathrm{E}_{3} \mathrm{C}_{1}$ & $\mathrm{o}$ & $\mathrm{o}$ & Excellent \\
\hline 7 & $\mathrm{M}_{4} \mathrm{E} 2 \mathrm{Co}$ & -2 & 10 & Excellent \\
\hline 8 & $\mathrm{M}_{4} \mathrm{E}_{4} \mathrm{C}_{1}$ & -2 & -5 & Good \\
\hline 9 & $\mathrm{M}_{4} \mathrm{E}_{3} \mathrm{C}_{1}$ & $\mathrm{o}$ & -12 & Poor \\
\hline 10 & $\mathrm{M}_{4} \mathrm{E}_{3} \mathrm{Co}$ & -2 & 10 & Excellent \\
\hline 11 & $\mathrm{M}_{4} \mathrm{E}_{3} \mathrm{Co}$ & -2 & 10 & Excellent \\
\hline 12 & $\mathrm{M}_{4} \mathrm{E}_{4} \mathrm{Co}$ & $\mathrm{o}$ & -15 & Poor \\
\hline 13 & $\mathrm{M}_{4} \mathrm{E}_{3} \mathrm{C}_{1}$ & -2 & 5 & Excellent \\
\hline 14 & $\mathrm{M}_{4}$ E2 Co & $\mathrm{o}$ & o & Excellent \\
\hline 15 & $\mathrm{M}_{4} \mathrm{E}_{3} \mathrm{Co}$ & -2 & 10 & Good \\
\hline 16 & $\mathrm{M}_{4} \mathrm{E} 2 \mathrm{C}_{2}$ & $\mathrm{o}$ & 10 & Excellent \\
\hline 17 & $\mathrm{M}_{4} \mathrm{E}_{4} \mathrm{C}_{1}$ & 2 & -5 & Excellent \\
\hline 18 & $\mathrm{M}_{4} \mathrm{E}_{4} \mathrm{C}_{1}$ & $\mathrm{o}$ & -5 & Good \\
\hline 19 & $\mathrm{M}_{4} \mathrm{E}_{3} \mathrm{C}_{1}$ & o & -10 & Good \\
\hline 20 & $\mathrm{M}_{4} \mathrm{E}_{4} \mathrm{C}_{2}$ & $\mathrm{o}$ & 10 & Excellent \\
\hline 21 & $\mathrm{M}_{4} \mathrm{E}_{3} \mathrm{Co}$ & 2 & o & Excellent \\
\hline 22 & $\mathrm{M}_{4} \mathrm{E}_{3} \mathrm{C}_{2}$ & $\mathrm{o}$ & 5 & Excellent \\
\hline 23 & $\mathrm{M}_{4}$ E2 Co & 2 & -15 & Poor \\
\hline 24 & $\mathrm{M}_{4} \mathrm{E} 2 \mathrm{Co}$ & -2 & o & Excellent \\
\hline 25 & $\mathrm{M}_{4} \mathrm{E}_{3} \mathrm{Co}$ & o & 0 & Excellent \\
\hline 26 & $\mathrm{M}_{4} \mathrm{E}_{3} \mathrm{Co}$ & $\mathrm{o}$ & $\mathrm{O}$ & Excellent \\
\hline 27 & $\mathrm{M}_{4} \mathrm{E}_{3} \mathrm{C}_{1}$ & $\mathrm{o}$ & $\mathrm{O}$ & Good \\
\hline 28 & $\mathrm{M}_{4} \mathrm{E}_{3} \mathrm{Co}$ & $\mathrm{o}$ & 10 & Excellent \\
\hline 29 & $\mathrm{M}_{4} \mathrm{E}_{3} \mathrm{C}_{1}$ & -2 & o & Excellent \\
\hline 30 & $\mathrm{M}_{4} \mathrm{E}_{3} \mathrm{Co}$ & $\mathrm{o}$ & $\mathrm{O}$ & Excellent \\
\hline 31 & $\mathrm{M}_{4} \mathrm{E}_{4} \mathrm{C}_{1}$ & -2 & 10 & Excellent \\
\hline 32 & $\mathrm{M}_{4} \mathrm{E}_{4} \mathrm{C}_{1}$ & o & 0 & Good \\
\hline 33 & $\mathrm{M}_{4} \mathrm{E}_{3} \mathrm{C}_{1}$ & -3 & 10 & Excellent \\
\hline 34 & $\mathrm{M}_{4} \mathrm{E}_{3} \mathrm{C}_{1}$ & $\mathrm{o}$ & $\mathrm{O}$ & Excellent \\
\hline 35 & $\mathrm{M}_{4} \mathrm{E}_{3} \mathrm{Co}$ & $\mathrm{o}$ & o & Excellent \\
\hline 36 & $\mathrm{M}_{4} \mathrm{E}_{3} \mathrm{C}_{1}$ & -2 & o & Good \\
\hline 37 & $\mathrm{M}_{4} \mathrm{E}_{2} \mathrm{C}_{1}$ & $\mathrm{o}$ & -10 & Poor \\
\hline 38 & $\mathrm{M}_{4} \mathrm{E}_{4} \mathrm{C}_{2}$ & $\mathrm{O}$ & $\mathrm{O}$ & Excellent \\
\hline
\end{tabular}


Citation: Persoons D. Preliminary results of new elastic mini-nail in the distal radius fractures. First 83 cases of the nail-o-flex nail. Asp Biomed Clin Case Rep. 2019 Sept 10;2(2):34-43.

Original Article

\begin{tabular}{|c|c|c|c|c|}
\hline 39 & M4 E2 C1 & 0 & 0 & Good \\
\hline 40 & $\mathrm{M}_{4} \mathrm{E}_{2} \mathrm{C}_{1}$ & $\mathrm{O}$ & -15 & Poor \\
\hline 41 & $\mathrm{M}_{4} \mathrm{E}_{4} \mathrm{C}_{1}$ & -2 & o & Excellent \\
\hline 42 & $\mathrm{M}_{4} \mathrm{E}_{3} \mathrm{C}_{2}$ & o & o & Good \\
\hline 43 & $\mathrm{M}_{4} \mathrm{E}_{4} \mathrm{Co}$ & -2 & 10 & Excellent \\
\hline 44 & $\mathrm{M}_{4} \mathrm{E}_{3} \mathrm{C}_{1}$ & -2 & $\mathrm{o}$ & Excellent \\
\hline 45 & M4 E3 Co Smith & o & $\mathrm{o}$ & Excellent \\
\hline 46 & $\mathrm{M}_{4} \mathrm{E}_{2} \mathrm{C}_{1}$ & -2 & o & Excellent \\
\hline 47 & $\mathrm{M}_{4} \mathrm{E}_{2} \mathrm{Co}$ & -2 & -10 & Good \\
\hline 48 & $\mathrm{M}_{4} \mathrm{E}_{3} \mathrm{Co}$ & 2 & -10 & Poor \\
\hline 49 & $\mathrm{M}_{4} \mathrm{E}_{3} \mathrm{C}_{1}$ & $\mathrm{o}$ & 5 & Excellent \\
\hline 50 & $\mathrm{M}_{4} \mathrm{E} 2 \mathrm{Co}$ & -2 & 10 & Excellent \\
\hline 51 & M3 E4 Co Smith & $\mathrm{o}$ & 15 & Excellent \\
\hline 52 & $\mathrm{M}_{4} \mathrm{E}_{4} \mathrm{Co}$ & -2 & 10 & Good \\
\hline 53 & $\mathrm{M}_{4} \mathrm{E}_{3} \mathrm{Co}$ & $\mathrm{o}$ & $\mathrm{O}$ & Excellent \\
\hline 54 & $\mathrm{M}_{4} \mathrm{E}_{2} \mathrm{C}_{1}$ & -2 & 5 & Excellent \\
\hline 55 & $\mathrm{M}_{4} \mathrm{E}_{4} \mathrm{Co}$ & -2 & $\mathrm{O}$ & Excellent \\
\hline 56 & $\mathrm{M}_{4} \mathrm{E} 2 \mathrm{Co}$ & $\mathrm{o}$ & $\mathrm{O}$ & Good \\
\hline 57 & $\mathrm{M}_{4} \mathrm{E}_{3} \mathrm{Co}$ & -2 & 5 & Excellent \\
\hline 58 & $\mathrm{M}_{4} \mathrm{E}_{2} \mathrm{Co}$ & $\mathrm{O}$ & $\mathrm{O}$ & Good \\
\hline 59 & $\mathrm{M}_{4} \mathrm{E}_{2} \mathrm{C}_{1}$ & 2 & $\mathrm{O}$ & Excellent \\
\hline 60 & $\mathrm{M}_{4} \mathrm{E}_{3} \mathrm{Co}$ & -2 & 5 & Excellent \\
\hline 61 & $\mathrm{M}_{4} \mathrm{E}_{3} \mathrm{C}_{1}$ & $\mathrm{o}$ & $\mathrm{O}$ & Excellent \\
\hline 62 & $\mathrm{M}_{4} \mathrm{E}_{3} \mathrm{Co}$ & -2 & 10 & Excellent \\
\hline 63 & $\mathrm{M}_{4} \mathrm{E}_{4} \mathrm{C}_{1}$ & $\mathrm{o}$ & 5 & Good \\
\hline 64 & $\mathrm{M}_{4} \mathrm{E}_{3} \mathrm{Co}$ & -2 & 10 & Excellent \\
\hline 65 & $\mathrm{M}_{4} \mathrm{E} 2 \mathrm{Co}$ & -2 & $\mathrm{o}$ & Excellent \\
\hline 66 & $\mathrm{M}_{4} \mathrm{E}_{3} \mathrm{Co}$ & -2 & $\mathrm{O}$ & Excellent \\
\hline 67 & $\mathrm{M}_{4} \mathrm{E}_{4} \mathrm{C}_{2}$ & 2 & -10 & Poor \\
\hline 68 & $\mathrm{M}_{4} \mathrm{E}_{3} \mathrm{Co}$ & -2 & $\mathrm{o}$ & Good \\
\hline 69 & $\mathrm{M}_{4} \mathrm{E}_{3} \mathrm{Co}$ & -2 & $\mathrm{O}$ & Excellent \\
\hline 70 & $\mathrm{M}_{4} \mathrm{E}_{4} \mathrm{C}_{1}$ & -2 & 5 & Excellent \\
\hline 71 & $\mathrm{M}_{4} \mathrm{E}_{4} \mathrm{C}_{1}$ & -2 & 5 & Excellent \\
\hline 72 & $\mathrm{M}_{4} \mathrm{E}_{3} \mathrm{C}_{4}$ & o & $\mathrm{O}$ & Good \\
\hline 73 & $\mathrm{M}_{4} \mathrm{E}_{3} \mathrm{Co}$ & -2 & 5 & Excellent \\
\hline 74 & $\mathrm{M}_{4} \mathrm{E}_{3} \mathrm{Co}$ & $\mathrm{o}$ & $\mathrm{O}$ & Excellent \\
\hline 75 & $\mathrm{M}_{4} \mathrm{E}_{3} \mathrm{C}_{1}$ & $\mathrm{o}$ & $\mathrm{O}$ & Good \\
\hline 76 & $\mathrm{M}_{4} \mathrm{E}_{3} \mathrm{Co}$ & $\mathrm{o}$ & 5 & Good \\
\hline 77 & $\mathrm{M}_{4} \mathrm{E}_{3} \mathrm{C}_{1}$ & -2 & 5 & Excellent \\
\hline 78 & $\mathrm{M}_{4} \mathrm{E}_{2} \mathrm{C}_{2}$ & o & $\mathrm{O}$ & Excellent \\
\hline 79 & $\mathrm{M}_{4} \mathrm{E}_{2} \mathrm{C}_{1}$ & $\mathrm{o}$ & 10 & Excellent \\
\hline 80 & $\mathrm{M}_{4} \mathrm{E}_{3} \mathrm{Co}$ & -1 & 10 & Excellent \\
\hline 81 & $\mathrm{M}_{4} \mathrm{E}_{3} \mathrm{Co}$ & 3 & -10 & Poor \\
\hline 82 & $\mathrm{M}_{4} \mathrm{E}_{3} \mathrm{Co}$ & -1 & 5 & Excellent \\
\hline
\end{tabular}


Citation: Persoons D. Preliminary results of new elastic mini-nail in the distal radius fractures. First 83 cases of the nail-o-flex nail. Asp Biomed Clin Case Rep. 2019 Sept 10;2(2):34-43.

Original Article

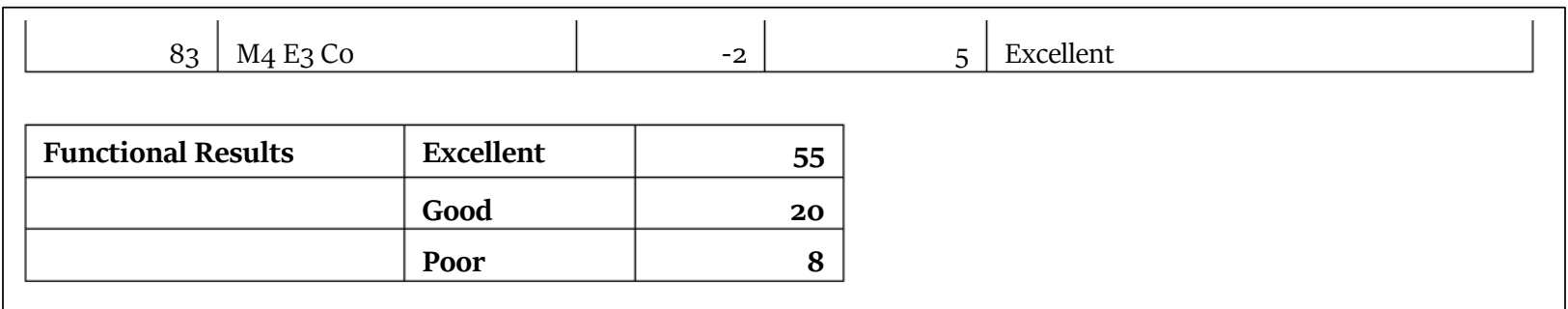

\section{Conclusion}

Distal radius pinning is proving itself to be logical and reliable. The "Nail-o-Flex ${ }^{\circledR}$ " nail was designed in 2005. Its aim was to offer an immediate stability along the radial shaft with an effective grip on the proximal diaphysis (3 support points). This seems to offer indeed a stable length restoration of the radius bone. With its 12 years of success records, the nail is a simple and inexpensive osteosynthesis implant. Its use is easy for any surgeon familiar with the pinning of the tibia. Its reliability is comparable to the best series of palmar plates. It requires only moderated X-ray irradiation.

\section{Conflict of interest}

The author of this article is the designer of the NOF nail. The present article regards a continuous and monocentric series of 83 patients treated by a nailing of their distal radius fracture. All the cases were operated by the designer and performer. The present articles, and clinical review, are not sponsored by any company. Dr. Persoons is totally free of any sponsorship.

\section{References}

[1] Wilcke MK, Hammarberg H, Adolphson PY. Epidemiology and changed surgical treatment methods for fractures of the distal radius: a registry analysis of 42,583 patients in Stockholm County, Sweden, 2004-2010. Acta Orthop. 2013 Jun;84(3):292-96. [PMID: 23594225]

[2] Alexandre C, Baudoin C, Bréart G, Constants T, Cormier C, Delmas P, Joël ME, Le Gales C, Lopes P, Savouret JF, Thomasset M. Ostéoporose: stratégies de prévention et de traitement. 1996: 85-87.

[3] Persoons D. Intramedullary nails in the treatment of the distal radius fractures. Eur J Orthop Surg Traumatol. 2018 Dec;28(8):1487-94. [PMID: 29948399]

[4] The Treatment of Distal Radius Fractures.
"Guidelines by AAOS. Point $\mathrm{n}^{\circ}$ 13,14 ; KeyRecommendations Adopted by the American Academy of Orthopaedic Surgeons": https://dailyrounds.org/library/distal-radiusfractures-treatmentguidelines-by-aaos. 2009.

[5] Tsuchiya F, Naito K, Mogami A, Obayashi O. New Technique for Dorsal Fragment Reduction in Distal Radius Fractures by Using Volar Bone Fenestration. J Orthop Case Rep. 2013 Apr-Jun;3(2):8-11. [PMID: 27298898]

[6] Desmanet E. Osteosynthesis of the radius by double elastic spring-pinning. Functional treatment of the distal end fractures of the radius. A study of 130 cases. Ann Chir Main. 1989;8(3):193-206. [PMID: 2818036]

[7] Kiintscher G. Die Tecknik der Marknagelung des Oberschenckels. Zbl f Chir. 1940;45:21-23.

[8] Rommens PM, Hessmann MH, editors. Intramedullary nailing: a comprehensive guide. Springer; 2015 Jan 12:3-7.

[9] MODNY MT, BAMBARA J. The perforated cruciate intramedullary nail: preliminary report of its use in geriatric patients. J Am Geriatr Soc. 1953 Aug;1(8):579-88. [PMID: 13084379]

[10] Kempf I. L'apport du verrouillage dans l'enclouage centro-medullaire des os longs. Rev Chir Orthop. 1978;64:635-51.

[11] Gradl G, Mielsch N, Wendt M, Falk S, Mittlmeier T, Gierer P, Gradl G. Intramedullary nail versus volar plate fixation of extra-articular distal radius fractures. Two year results of a prospective randomized trial. Injury. 2014 Jan;45 Suppl 1:S3-8. [PMID: 24268189]

[12] Obert L, Leclerc G, Clappaz P, Lepage D, Bonin N, Jeunet L. Pinning, Dorsal Plate or Volar Plate For Fractures Of The Distal Radius With Dorsal Displacement: Functional Analysis Of A Prospective Comparison of 62 Consecutive Cases. 2008 Jul;9o(Supp_Ii):277.

[13] Diaz-Garcia RJ, Oda T, Shauver MJ, Chung KC. A systematic review of outcomes and complications of treating unstable distal radius fractures in the elderly. 


\section{Original Article}

J Hand Surg Am. 2011 May;36(5):824-35. [PMID: 21527140]

[14] Hull P, Baraza N, Gohil M, Whalley H, Mauffrey C, Brewster M, Costa ML. Volar locking plates versus $\mathrm{K}$-wire fixation of dorsally displaced distal radius fractures--a functional outcome study. J Trauma. 2011 Jun;70(6):E125-8. [PMID: 20693924]

[15] Margaliot Z, Haase SC, Kotsis SV, Kim HM, Chung KC. A meta-analysis of outcomes of external fixation versus plate osteosynthesis for unstable distal radius fractures. J Hand Surg Am. 2005 Nov;30(6):1185-99. [PMID: 16344176]

[16] Mattila VM, Huttunen TT, Sillanpää P, Niemi S, Pihlajamäki H, Kannus P. Significant change in the surgical treatment of distal radius fractures: a nationwide study between 1998 and 2008 in Finland. J Trauma. 2011 Oct;71(4):939-42. [PMID: 21986738]

[17] Pino S, Bonila J, Borras J. Comparative study of distal radius fracture treated with volar plate or external fixation. J Bone J Surg. 2011 May;93(Supp_II):169. 